\title{
The United Church of Canada Board of Publication Collection: A Major Resource for the History of the Book in Canada
}

Dana Garrick ${ }^{\dagger}$

\section{Introduction}

Due to natural disasters and publishers' neglect, the extant records of nineteenth-century Canadian publishing houses are not abundant. Fortunately, many of the records of the Methodist Book and Publishing House, whose general publishing name William Briggs in 1919 became the Ryerson Press, ${ }^{\mathrm{I}}$ have survived in the United Church Archives at Victoria College. A careful examination of these 'fragmentary' documents enhances our knowledge of how books and periodicals came to be published, manufactured, and distributed in nineteenth-century Canada. They also allow us to understand how the Methodist Book and Publishing House went about its business of disseminating 'pure literature' and making money from I 829 to 1926 , and, incidentally, publishing some of the seminal works of Canadian literature. ${ }^{2}$

The United Church of Canada Board of Publication Collection consists of four series of records. ${ }^{3}$ The first series contains the publishing records of the Methodist Church from I 836 to I926. The surviving documents pertaining to the Methodist Book and Publishing House include the Journals of the Book and Publishing Committee, ${ }^{4}$ the book steward's records, business and financial records, legal records, labour records, correspondence, and agreements with authors and publishers.

The second series contains the records of the Board of Publication from 1926 to 1968 . The newly formed United Church created this board in 1926 to oversee the denominational literature published by

$†$ Dana Garrick is a doctoral student in sociology at the University of Toronto. His paper was read at the Annual General Meeting of the Bibliographical Society of Canada in Hamilton, Ontario, on I6 June 1993. 
the United Church Publishing House - the successor to the Methodist Book and Publishing House; and the general literature published by the church's trade imprint the Ryerson Press. The Ryerson Press was sold in I97I, but the United Church Publishing House is still active. The third series in the collection consists of the records of the Ryerson Press from I9I9 to I97I. The final series contains documents relating to the various buildings occupied by the publishing house; these documents date from I808 to I960.

The United Church Archives also hold the personal papers of many individuals named in the Board of Publications documents. Egerton Ryerson is an obvious example, but John Douse is not; yet Douse's papers contain the manuscript for a hymn and tune book which is the centre of many pages of discussion in the Journals of the Book Committee. ${ }^{5}$ The United Church Archives have recently published an indexed guide to its textual records. This research tool, which provides descriptions, finding-aid numbers, and location numbers, facilitates the process of accessing the holdings of the archives. $^{6}$

\section{The Origins of the Methodist Book and Publishing House}

Methodism and publishing have been linked since 1740 when John Wesley, the founder of Methodism, began publishing denominational literature and selling books and tracts at the Foundry in London. Wesley stressed the importance of self-education through reading to both his followers and his preachers, and he personally wrote hundreds of works and simplified others including Pilgrim's Progess and Paradise Lost in order to make them accessible to individuals with limited reading experience.

Methodism arrived in North America in 1766. In I789, the American Conference decided to establish a book concern which was located in Philadelphia until 1804 when it moved to New York. In I 824, Nathan Bangs, who in I 800 had been one of the first American Methodist circuit preachers to come to Upper Canada, bought a Stanhope press for the New York establishment and opened a printing office. Five years later the Canadian Methodist Conference meeting at Ancaster decided that '. . . a weekly paper should be established under the direction of the Conference, of a religious and moral character, to be entitled the Christian Guardian. ${ }^{17}$ The Conference elected Egerton Ryerson to be both the first editor of the Christian Guardian and the first book steward (I829-32). The 
Conference then sent Ryerson to New York with $\$ 700.00$ to buy a wooden hand-press and type. The Conference also appointed a publishing committee of five persons, including the General Superintendent of the church, to supervise the publishing of the Guardian and all other printing done in the Guardian office. The committee was to oversee the financial affairs of the business, and in consultation with the editor of the Guardian and the book steward, was to be '... responsible to the Conference for the general management of the Guardian, and all other publications issued from the Book Room. ${ }^{8}$

The resolutions which established the Christian Guardian and the Methodist publishing concern in 1829 , as well as the resolutions which established the book room a few years later (I833) can be found in the Minutes of Conference of the Methodist Church in Canada. ${ }^{9}$ The various published Minutes of Conference also specify the relationship of the publishing house to the church, and they outline the duties of the book steward, the editor, and the book and publishing committee.

The book steward was the manager of the publishing concern. He was responsible for purchasing presses, type, and paper, for maintaining the stock of books and tracts, for keeping records of cash and credit sales and of debts to the house, and also for tabulating the circulation of the periodicals. In addition, the Conference resolved that the book steward:

. . . shall carefully examine . . all Books, \&c., which may be published on behalf of the Conference, and employ those stitchers, binders, and artists who shall do their work best, and upon the most reasonable terms; and in all these things shall act in accordance with the advice of the Committee. ${ }^{\text {IO }}$

\section{The Dissemination of Pure Literature}

The Methodist Book and Publishing House began its life with conflicting goals. The Conference intended the Christian Guardian to be the denominational organ of the church, but under the editorship of Egerton Ryerson, the Guardian soon became the voice of the Methodist church in its political struggles with the ruling elite and the Anglican hierarchy to obtain legal recognition and a just settlement of the clergy reserves question in Upper Canada. The Methodist Conference also expected their denominational press to dis- 
seminate pure literature - to spread the Methodist word of evangelical Christianity. But from its inception the publishing concern of the church was also expected to make money, and any profits were to be used for the benefit of superannuated and 'worn-out' preachers.

Between I 854 and I 884 Methodism was transformed from a rural and working class evangelical sect into a middle-class urban church that had also become the largest Protestant denomination in the Dominion. A pragmatic policy of consolidation of the powerful Methodist organization replaced the proselytizing missionary ideology of its growth phase. Unifications of the various Methodist sects in 1854 and again in 1874 culminated in the creation of the Methodist Church of Canada in I 884; after I 884, negotiations began with other Protestant churches which lasted until the formation of the United Church of Canada in 1925.

As a result of these conflicting goals, a constant tension between ideas and interests appears as a recurrent theme in documents and publications emanating from the Methodist Book and Publishing House. In the late Victorian era, long after the publishing house had become a major business enterprise whose profits were crucial to the finances of the Methodist church in an era of stagnant membership growth, the church continued to reiterate the benefits of disseminating pure literature. The Quadrennial Report of I894 declares: 'From our presses and our shelves we have sought to send out a stream of clean, wholesome literature into every part of this great Dominion, seconding the effort of the Pulpit and the School toward the moral uplifting and enlightening of the masses. ${ }^{\prime I}$

During the late nineteenth century, the tension between ideas and interests increased as general publishing became the predominant and very profitable business of the house. The Methodists had been publishing 'uplifting' non-denominational literature since I 835 when the book steward, Matthew Lang, published James Everett's The Village Blacksmith which Joseph $\mathrm{H}$. Lawrence printed from the fifth English edition. ${ }^{2}{ }^{2}$ In the early days ideology may have predominated in the decisions of the publishing concern, but under the stewardship of Anson Green (1843-54 and I859-65), who brought the first steam press to Canada in $185 \mathrm{I}$, business considerations began to predominate. ${ }^{13}$ The house's 1844 catalogue lists approximately 500 items, but only a few titles were its own publications. Samuel Rose, book steward from I856 to I879, consolidated the business organization of the house and increased the volume of general publishing. The 1876 catalogue notes that forty-five titles 
are publications of the house. By the time William Briggs (I 8791919) succeeded Rose as book steward in 1879 his mandate allowed him to publish anything that fell within the norms of late Victorian taste as long as it made money. ${ }^{14}$ The Methodist Book and Publishing House catalogue for I 886 lists approximately I 5,000 items in stock and notes I4I titles as 'Books We Publish.' I5

The Quadrennial Reports prepared for the General Conference from 1878 to 1906 reflect the tension between making money and spreading the word. The reports always stress the dissemination of pure literature while simultaneously emphasizing the profits that general publishing contributed to the house. William Briggs's I 882 report opens with the statement:
... whilst it is desirable that satisfactory results, from a purely commercial standpoint, should be reached in the management of the Book and Publishing House, yet 'making money' is not the only object aimed at. The grand moral results which must flow from the dissemination of so large a quantity of sound Christian literature as has been circulated by this Establishment, are such as cannot be measured by rules of arithmetic, but reach into Eternity. ${ }^{16}$

Briggs, who had been the pastor of the Metropolitan Church - the 'Methodist Cathedral' in Toronto - before being elected book steward, was a powerful figure in the Methodist organization. In I 885, he was elected President of the influential Toronto Conference. Briggs became a very successful businessman who used the publishing house to make as much money as possible for the church for forty years. Under Briggs's management, the Methodist Book and Publishing House became the largest publisher in Canada and an extremely profitable business organization. What is fascinating, however, is why he chose aggressively to undertake original Canadian publishing when he did. Briggs's Quadrennial Reports show that he was proud of the fact that the Methodist Book and Publishing House was the leading publisher of 'Canadian literature' works about Canada by Canadians. ${ }^{17}$

This 'golden age of Canadian publishing' lasted from the early I 880 s to about 1908 . For a number of reasons, including changes in the Copyright Act, Briggs then gradually shifted to agency publishing which was very profitable without requiring large capital risks. ${ }^{18}$ During Briggs's stewardship the stated goal of the house remained the dissemination of pure literature, but the agency titles that Briggs published were not all pure literature, nor were some of 
his 'Canadian' publications such as the works of Robert Service. Nevertheless, there appears to be no documentary evidence that Briggs ever had to justify his publishing decisions to either the publishing committee or to the General Conference of the Methodist church. The very few recorded occasions when Briggs had to explain his actions to the publishing committee were in response to questions regarding his financial management. ${ }^{19}$ Individuals twice accused Briggs of publishing objectional literature, but the committee brushed these allegations aside. ${ }^{20}$

During Briggs's stewardship, documents show how Copp, Clark and Co., W.J. Gage and Co. and the Methodist Book and Publishing House, all located in Toronto, tried to control prices in the profitable textbook trade. ${ }^{21}$ Documents elsewhere also show the attempts of other publishers, notably George Morang, to penetrate that market. ${ }^{22}$ Whenever Briggs wrote to the Ontario Minister of Education to solicit authorization for a new textbook, Briggs would remind the minister, who effectively controlled publishers' access to the textbook industry in Ontario and, ultimately, across the country, that the Methodist Book and Publishing House had done more for Canadian literature and history than all the other Toronto publishers combined. ${ }^{23}$

An 'elective affinity' between Methodist doctrine and the spirit of modern capitalism provided the incentive for many Methodists to become very successful in this world. Methodist influence permeated the Ontario educational system run for thirty years by Egerton Ryerson ${ }_{i}^{24}$ and the pragmatic and ascetic Methodist ideology suffused the world of business and government in late nineteenthcentury Toronto. Journal entries, agreements, and correspondence record business dealings with, among others, George W. Ross, Minister of Education and later Premier of Ontario, Timothy Eaton, and financier Joseph Flavelle; and reveal how these worldly and successful Methodist politicians and businessmen interacted with the Methodist Book and Publishing House. Given the house's hold on textbook publishing and its position as the largest publisher in Canada, we might ask what impact this intermingling of religious, political, and business elites had on the spread of ideas in Canada.

\section{The Records of the Methodist Book and Publishing House}

The Journals of the Book and Publishing Committee, extant from I 836, contain hundreds of pages of decisions related to publishing. 
Many of these discussions focus on the denominational periodicals - the Christian Guardian, the Canadian Methodist Magazine, and the many Sunday school publications. The Methodist organization was obsessed with statistics; ${ }^{25}$ and the Journals provide extensive financial data for the publishing house, book room, and periodicals. They also record circulation figures for the periodicals. In addition, full financial statements and circulation data for the period 1878 to I906 can be found in the Quadrennial Reports. The archives also hold records of cash and credit sales, receipts and expenditures, financial reports, and balance sheets from I 889 through to the sale of Ryerson Press in I97I.

An ongoing theme in the Journals is the publication and frequent revision of the Doctrines and Discipline of the Methodist Church in Canada. ${ }^{26}$ Frequent entries deal with the other denominational works and the many hymn and tune books published by the house. Four authors figure prominently in the proceedings of the Journals: Alexander Davidson, George F. Playter, George H. Cornish, and John Carroll. Resolutions dissociating the Conference from Egerton Ryerson's political activities appear; and the committee discusses many other authors and titles, including lengthy deliberations leading to a decision to publish the journals of Rev. Peter Jones which had to be postponed because the committee forgot to read Jones's will. In I 860, Anson Green published the manuscript as the Life and Journals of Kah-ke-wah-quo-na-by.

The first recorded meeting in the Journals (I5 August I836) contains a reference to Alexander Davidson's Sacred Harmony. ${ }^{27}$ Subsequent journal entries tell the story of this book from inception through publication to revision and subsequent editions. Because this was a music book, the committee sent James Evans to New York to have the work printed 'part in plain, and part in patent notes' (I 5 July I 837 ). There he was advised that stereotyping would be cheaper than a letterpress edition. With the publishing committee's approval, the work was stereotyped and subsequently imported to Toronto in sheets. Sacred Harmony is listed in Anson Green's I 844 house catalogue.

On I7 March I 853, the Journals record the first surviving contract between the publishing house and an author. The book committee decided to publish 2,000 copies of Elan Tupper's An Introduction to the Science of Vocal Music with the stipulation: 'That the words set to the examples be subject to the approval of the Book Committee.' Tupper was to receive ten per cent on all wholesale purchases after enough copies had been sold to pay the expenses of the publication. 
The Methodist Book and Publishing House catalogue for 1886 lists six titles by John Carroll (I 809-84). The Journals first refer to Carroll on 7 May I 866. Subsequent entries indicate that Carroll was the house manuscript editor, and disclose that the book committee commissioned Carroll to write Case and His Cotemporaries; or, The Canadian Itinerants' Memorial, published in I 867. The Journals (4 August I 870) record a very specific financial settlement made to Carroll in return for providing a manuscript for which he would be paid no royalties nor retain any residual rights. The committee agreed to pay Carroll \$200.00 for each of the first four volumes, but only after I, ooo copies of each had been sold and stipulated that '. . . the completed work [would] be the property of the Book Room, no exception being allowed either in reference to the United States, England or in any part of the Dominion.'

In September 1850, George F. Playter, a former editor of the Guardian (I844-46), proposed a Christian Library to the house which the committee agreed to publish. Playter was to provide the paper and to pay the costs of publication. He failed to comply with the agreement, and in August I 854, the book steward directed the printer to distribute the type which had been set for the work.

The house published Playter's History of Methodism in Canada in I862. Sales of the book did not meet expectations, and in November 1864, the book steward was forced to take over the unsold stock to recover Playter's debt to the house. In August I 867, a year after Playter's death, his widow sent the manuscript of the second volume of the History to the committee for publication. They declined to publish but did not return the manuscript until February I 87I, after removing all the extracts that Playter had cut from the files of the Guardian.

In 1867 the house also published George H. Cornish's Handbook of Canadian Methodism. Cornish reworked this material, and in I88I, the house published the Cyclopaedia of Methodism in Can$a d a$; a second volume appeared in $1903 .{ }^{28}$ Both the Handbook and the Cyclopaedia were published by subscription. The Handbook of Canadian Methodism is not listed in W. Stewart Wallace's The Ryerson Imprint (1954). The Cyclopaedia of Methodism in Canada appears in the house's I 886 catalogue, and Wallace does record it.

Scholars will find very rich material in the Notebooks of Costs of Various Printed Materials, I88I-90, and the Ledger, Costs of Publication and Sale of Selected Works, I 906-1 3. These ledgers detail 335 items from I 88I to I890 and I94 items from I 906 to I9I 3. Many historically significant titles appear in these ledgers which list costs 
of imported sheets, stereoplates, presswork, imposition, corrections, paper, binding, illustrations, and royalties, as well as calculations of wholesale and retail prices. Some entries, for example, those of Robert Service and Charles Mair, also include invaluable publishing information.

These ledgers, along with catalogues, correspondence, and agreements provide evidence for the existence of many titles not listed in Wallace's Ryerson Imprint; and they facilitate the very real necessity of updating this checklist to include the many books which Wallace either missed or 'silently passed over.'29

The Manuscript Record Book, I9IO-I3, lists manuscripts received, read and returned to the author or, in a very few cases, published by the house. Titles of submitted manuscripts give us an insight into Canadian popular culture in the first decade of this century. This notebook also offers clues to the role of various employees of the house who acted in the manuscript selection process (E.S. Caswell, E.W. Walker). Entries show that the house circulated manuscripts to publishers in the United States and Britain. Thurlow Fraser's The Life Healer, for example, went from Doran, to Dodd, Mead, to Appleton, to Revell. The notebook includes manuscripts by Robert Service, J.W. Tyrell, J.P. Buschlen, and George W. Ross - authors for whom other documentation exists.

The confidential Quadrennial Reports of the Western Section of the Book Committee, 1878-1906, were prepared for members attending the General Conferences of the church. They are an essential source of financial and circulation data and for information about technological developments within the house. These reports describe the operations of the printing, binding, and engraving departments as well as the wholesale and retail business. They also discuss many of the books and periodicals published by the Methodist Book and Publishing House; and they record the growing importance of trade publishing to the enterprise. William Briggs obliquely inserts a reference to trade publishing into the 1882 report under the rubric of the 'Wood Engraving Department,' which also notes that from I 878 to 1882 , the house had printed nearly 20,000 volumes of 'premium' books and, in addition, had introduced an electrotyping and stereotyping department.

The William Briggs Agreements comprise $27 \mathrm{I}$ contracts which Briggs negotiated with authors and publishers. Agreements with Canadian authors include William Wilfred Campbell, Ralph Connor, Nellie McClung, Theodore Rand, and Edward W. Thomson. 
Publishers include the Cambridge University Press, William Collins and Sons, Dodd, Mead and Co., William Heinemann, Harper and Bros., Thomas Nelson, Charles Scribner's Sons, and T. Fisher Unwin..$^{30}$ The William Briggs's Correspondence contains an extensive exchange with Henry Morgan which documents Morgan's The Canadian Men and Women of the Time through two editions from I 898 to $1915 .{ }^{3 \mathrm{I}}$

These agreements and correspondence elucidate the complex relationships among American, British, and Canadian publishers. They also help us to understand the relationship between author and publisher. In addition, these documents help to unravel the networks of distribution of both ideas and publications which linked London and New York, and Toronto, and Toronto with the rest of Canada.

In an attempt to counter the many American and British firms that set up agencies in Canada in the I890s, the Methodist Book and Publishing House and Copp, Clark and Co. made a series of pricefixing agreements beginning in 1896 ; and, in 1899 , both firms agreed not to compete against each other by importing British or foreign editions when either firm had arranged for a Canadian issue of a book..$^{32}$ The Methodist Book and Publishing House also maintained price-fixing arrangements with the large Methodist publishing enterprises in Britain and the United States.

The Journals, Quadrennial Reports, contracts, and correspondence record purchases made by the house, tracing innovations in printing, binding, and illustrating. The Methodist Book and Publishing House was in business to make money and, because economies of scale are essential in publishing, introduced new technology on a timely basis. Agreement no. 139, for example, shows that the house first acquired linotype machines in 1894 ; and no. 234 records the rental of a colour printing process in $190 \mathrm{I}$.

The Printers Wage Book, I883, financial ledgers, and employees' verbatim reminiscences give us a picture of workers in a nineteenthcentury publishing house. These same documents provide insights into the role of women in the printing office and the bindery. The wage books indicate that the house employed women in the news room, press room, and job room; and may also have employed women as compositors. ${ }^{33}$ A letter on file tells us about Miss Robbins, the 'forelady of the bindery' who supervised both male and female employees. ${ }^{34}$ And Rosa Gilkes recalls her editorial work with W.H. Withrow on the Sunday school publications. 'Miss' as a title of address is not used for employees in the next Printer's Wage 
Book, I885-86, but we can trace Miss Austin, who appears in the I 883 ledger, in the press room from 5 September I885 to 24 June I887. A careful study of all the wage books may reveal the extent of the role of women in the publishing house.

The Stock Book from the 1890 s lists the wide range of authors and titles carried by the Methodist Book and Publishing House along with the names of the various British and American publishers with whom the house did business. This stock book shows, for example, that the house carried the works of Charles Darwin even though it was the 'evolutionary challenge' which posed the most serious threat to the church in the late nineteenth century. E.H. Dewart, editor of the Christian Guardian, and W.H. Withrow, editor of the Canadian Methodist Magazine, were among the leaders of the conservative reaction to the new scientific challenges to traditional doctrine. Recently, however, Michael Gauvreau has argued in the Evangelical Century, that many Protestant intellectuals such as Nathanael Burwash, President of Victoria College, were able to absorb the new scientific theories and critical reassessments of the Bible into their theological thought. ${ }^{35}$ This theological flexibility was compatible with the Methodist goals of consolidation and accommodation in the late nineteenth century. The Methodist Book and Publishing House was easily able to include the works of Charles Darwin, Mark Twain, and Conan Doyle, as well as the theological expositions of Nathanael Burwash in its list of publications, along with Bibles, hymn books, and temperance tracts - the sole proviso being that they had to make money. ${ }^{36}$

RÉSUMÉ

Cet article examine les abondantes sources d'information pour l'étude de l'histoire du livre que l'on peut trouver dans la collection du Conseil d'Édition de l'Église Unie du Canada qui se trouve aux Archives de l'Université Victoria de Toronto. L'auteur esquisse l'historique du rôle de l'Église Méthodiste dans le domaine de l'édition; traite brièvement des débuts du Christian Guardian, ainsi que de la fondation, en I829, de la bibliothèque et maison d'édition méthodiste. Il décrit les fonctions du comité du livre, du commis et de l'éditeur. Il suggère certains sujets d'étude que les chercheur(e)s pourraient poursuivre en utilisant les documents de cette collection. 


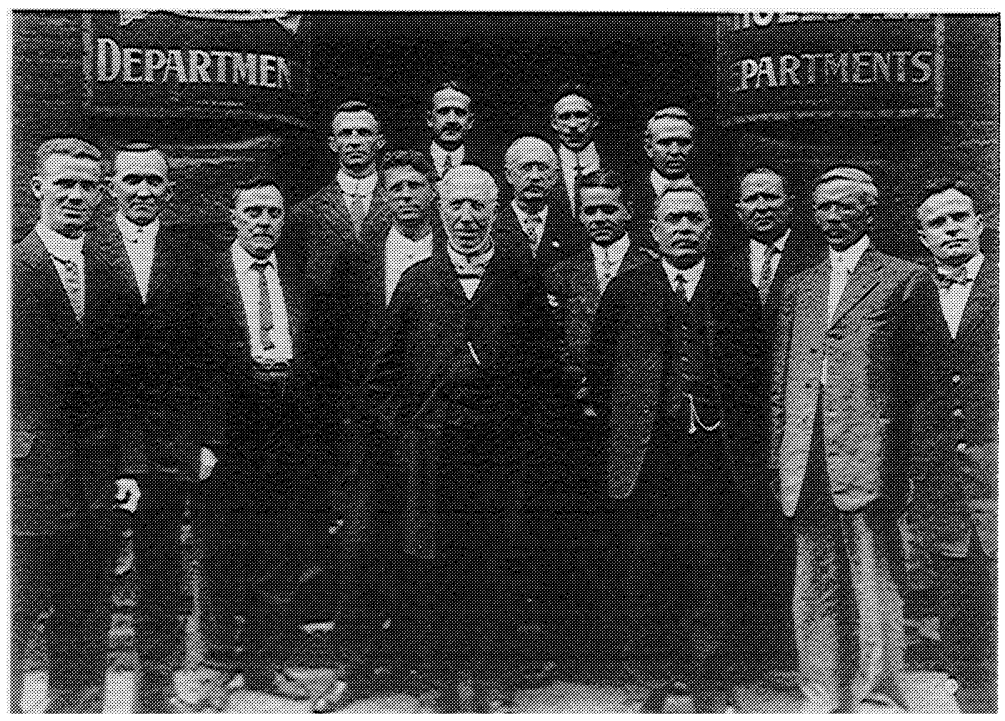

I. The management of the Methodist Book and Publishing House in I9I0. Photographed outside the entrance to the wholesale and manufacturing departments at 28-36 Temperance Street, Toronto.

From left to right: John Ferris, manager library department; James Portch, entry room clerk; Arthur J. Rugg, foreman of bindery; W.C. Kettlewell, accountant; Sid Ewing, editor and advertising; E.W. Walker, manager wholesale book department; William Briggs, book steward; Rev. J.J. Reddit, assistant to book steward; Mr. Kerr, clerk retail store; W.L. Cope, factory superintendent; James Dale, manager periodical business office; W.B. Creighton, editor of the Christian Guardian; John Barber, foreman press room; Richard Whittaker, manager retail department; A.H. Kirby, maintenance engineer. (Courtesy of the United Church of Canada / Victoria College Archives, Toronto.) 


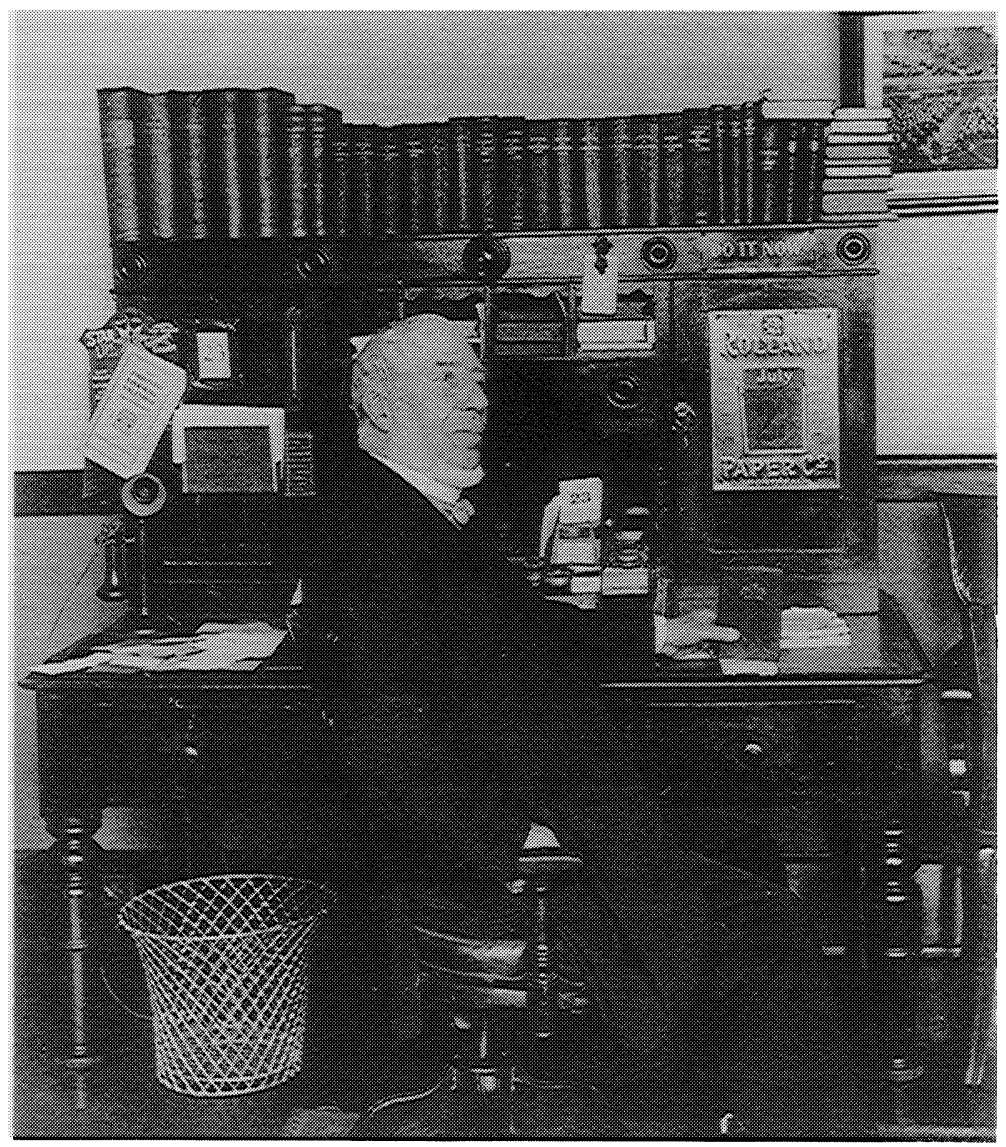

2. William Briggs, holding The Primitive Methodist Hymnal, at his desk in the Richmond Street building with the motto Do IT NOW - in red type pinned to his desk. The books on top of the desk include the Minutes of Conference I907. (Courtesy of the United Church of Canada / Victoria College Archives, Toronto.) 


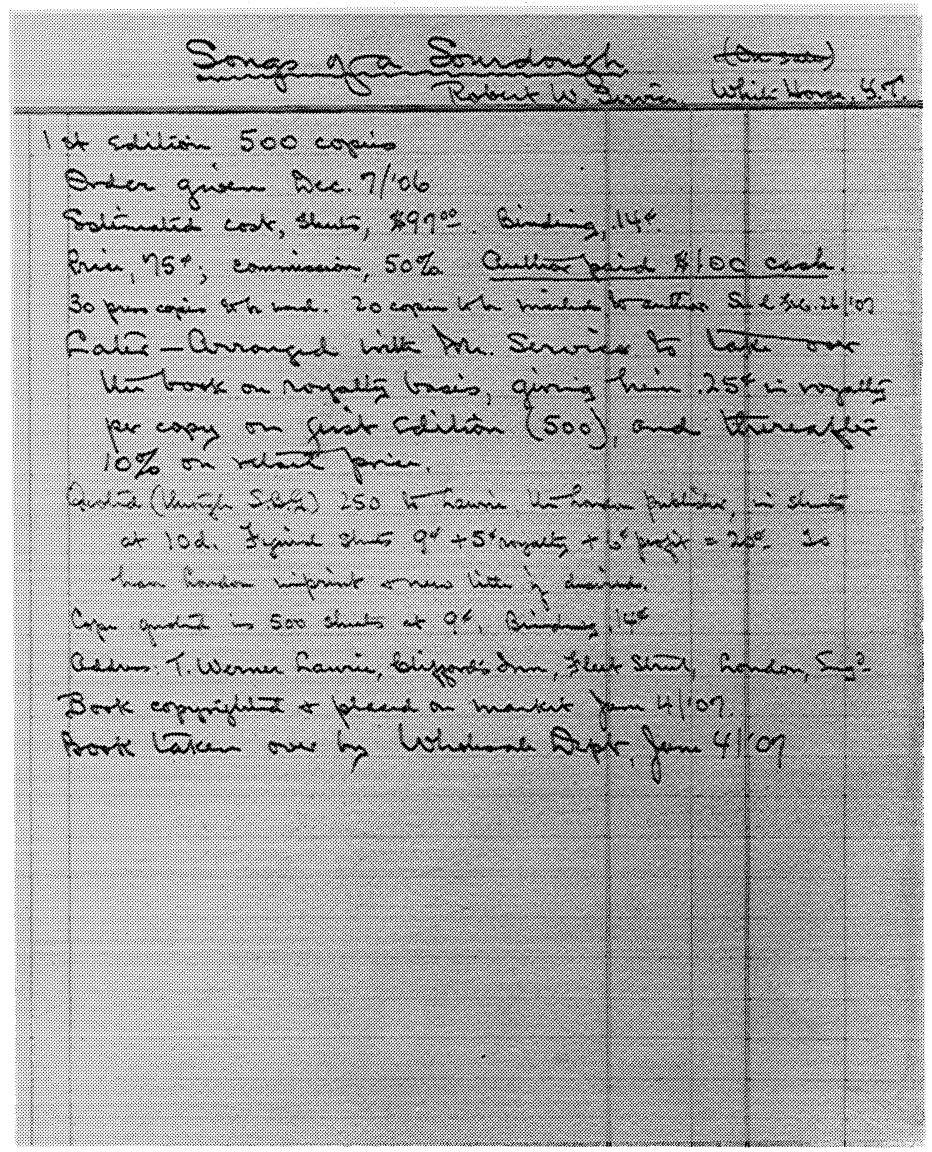

3. P. 4 from the Ledger, Costs of Publication and Sale of Selected Works, I906-I3. The Methodist Book and Publishing House originally bought the manuscript of Songs of a Sourdough from Service for \$100.00. The house soon realized the value of the work, and arranged a royalty agreement with him. (Courtesy of the United Church of Canada / Victoria College Archives, Toronto.) 


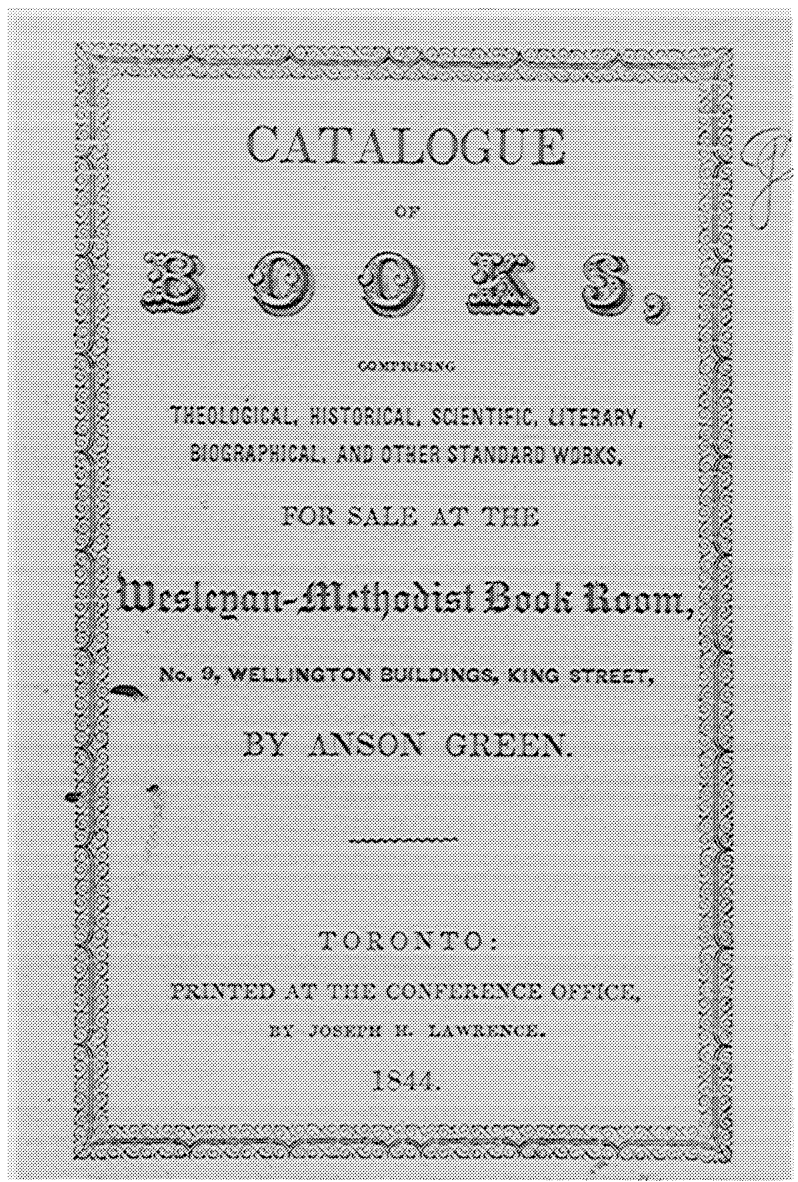

4. The catalogue of the Wesleyan Methodist Book Room published by the book steward, Anson Green, in I 844 . (Courtesy of the Metropolitan Toronto Reference Library.) 


\section{NOTES}

I See the Journals of the Book and Publishing Committee, 7 May I9 19:

Whereas the name Wm. Briggs has been used as a trade name by the Methodist Book and Publishing House we hereby authorize the Book Steward to secure, through proper legal means, the registration of the name 'The Ryerson Press,' which name would be used as a trade name where 'Wm. Briggs' is now used, to take effect on July Ist I9I9.

Unless otherwise indicated, all references to archival documents are to Fonds 513. United Church of Canada Board of Publication Collection. Finding Aid: 35, Location no.: 83.06 Ic. United Church of Canada / Victoria University Archives in the University of Toronto.

2 For simplicity, I will call all the permutations of Wesleyan, Methodist, and Methodist Episcopal sects 'Methodist.' I will also call the publishing house the Methodist Book and Publishing House, although it used many other names prior to the unification of 1874 .

3 Fonds 513. Finding Aid: 35, Location no.: 83.06 IC.

4 Journal of Proceedings of the Book Committee, 1836-55; Journal of the Book Committee, 1855-74; Minutes of Annual Meeting of the Western Section of the Book and Publishing Committee, I 875-98; Minutes of Annual Meeting of the Western Section of the Book and Publishing Committee, 1898-1913; and Minutes of the Book and Publishing Committee, r9 13-26.

5 The Egerton Ryerson Fonds, Finding Aid: 26, Location no.: 86.218c; The John Douse Fonds, Finding Aid: 132, Location no.: 86.088c. See also the papers of Nathan Bangs, Nathanael Burwash, Albert Carman, Samuel Chown, Richard Jones, Morley Punshon, and Mathew Richey.

6 Ruth Dyck Wilson with Peter D. James, A Record of Service: A Guide to Holdings of the Central Archives of the United Church of Canada (Toronto: United Church of Canada / Victoria University Archives, 1992).

7 The Minutes of the Annual Conferences of the Wesleyan Methodist Church in Canada, from I824 to I845, Inclusive; with Many Official Documents and Resolutions Not Before Published. To Which is Added the Marriage Act (Toronto: Published by Anson Green, Conference Office, 1846). See Minutes of Conference, I829, p. 27. Article I.

8 Ibid. Minutes of Conference, I837, p. 155 . 'Concerning the Editor.' Article 5.

9 The Minutes of Conference for the years 1824 to 1857 are collected in the following two volumes: The Minutes of the Annual Conferences of the Wesleyan Methodist Church in Canada, from I 824 to I845, Inclusive; With Many Official Documents and Resolutions Not Before Published. To Which is Added the Marriage Act (Toronto: Published by Anson Green, Conference Office, 1846); and The Minutes of Twelve Annual Conferences of the Wesleyan Methodist Church in Canada, from I 846 to I 857 Inclusive, with an Index. Condensed and Published by Direction of the Conference (Toronto: Published by Anson Green, Conference Office, 1863). Vol. 2. From I 857 to I 874, the Minutes of Conference were published annually. After I874, the Minutes were published quadrennially. 
Io The Minutes of the Annual Conferences of the Wesleyan Methodist Church in Canada, from I824 to I845. Minutes of Conference, I837, p. I55. 'Concerning the Book Steward.' Article 5.

I I Quadrennial Report r894, 4.

12 See no. 832 in Patricia Lockhart Fleming, Upper Canadian Imprints, I80II84I: A Bibliography (Toronto: University of Toronto Press, I988), 224-25. Joseph H. Lawrence was a founder of the York Typographical Society in 1832 . The Journals of the Publishing Committee contain many resolutions concerning Lawrence (ro May I 843; 8 October I 844; and I August I855).

I3 Anson Green, The Life and Times of the Rev. Anson Green, D.D. (Toronto: Methodist Book Room, i 877).

I4 In both The Chronicle of a Century, I 829-1929: The Record of One Hundred Years of Progress in the Publishing Concerns of the Methodist, Presbyterian and Congregational Churches in Canada (Toronto: United Church Publishing House, Ryerson Press, n.d. [ca. I930]) and The House of Ryerson, I 829-1954 (Toronto: Ryerson Press, 1954), Lorne Pierce states that William Briggs retired in 1918 when he was replaced by Samuel Fallis, but the Journals of the Book and Publishing Committee clearly show that Briggs was still book steward and a member of the publishing committee at the annual meeting held on 7 May I9I9. Fallis is not a committee member on 7 May 1919 , but is referred to in a resolution as 'book steward elect.' The adoption of the trade name 'Ryerson Press' to replace 'William Briggs' became effective I July I919. At the committee meeting held on 19 November 1919, Briggs is introduced as 'Book Steward Emeritus' and made a corresponding member of the committee. This evidence indicates that Fallis's stewardship became effective after 7 May 1919, perhaps on I July I 9 I 9.

I5 Anson Green, Catalogue of Books, Comprising Theological, Historical, Scientific, Literary, Biographical, and Other Standard Works, for Sale at the Wesleyan-Methodist Book Room (Toronto: Conference Office, 1 844); Samuel Rose, General Catalogue of Books, Published and on Sale at the Methodist Book and Publishing House (Toronto: Guardian Book and Job Establishment, 1876-77); William Briggs, General Catalogue of Books, Published and on Sale at the Methodist Book and Publishing House (Toronto: William Briggs, I886). The 1884 and 1886 catalogues are located at the Baldwin Room, Metropolitan Toronto Reference Library; the 1876 catalogue is at the United Church of Canada Board of Publication Collection.

I6 Quadrennial Report I882, p. 3.

I7 Quadrennial Report 1902, p. 7. William Briggs states:

As a publishing house we may safely claim to have maintained the previously well-established reputation for the number and importance of the works issued from our presses. A pleasing feature in this connection is the many valuable books by Canadian writers shown in our lists in recent years.

18 George Parker, The Beginnings of the Book Trade in Canada (Toronto: University of Toronto Press, I985), 255-56.

19 See the Journals of the Book and Publishing Committee, I6 May r9or:

Your Committee, anxious to preserve the traditional policy of the Book Room 
as to the nature of the literature it issues, have carefully considered the criticisms contained in 'The Open Letter' of the Rev. E.R. Young, Sr., addressed to the General Superintendent, and by him forwarded to the Book Committee, as well as the reply of the Rev. Dr. Briggs in the document submitted to the Committee, beg to report as follows:

Ist. Your Committee are of the opinion that the statements of the Rev. E.R. Young, Sr., as to the financial showing of the Book Room are inaccurate and made without full knowledge of the real facts, as the accounts and auditor's reports of the institutions fully testify.

2nd. Your Committee are of the opinion that every reasonable care has been observed by our Book Steward and all in authority under him to carry out the object for which the Book Room was established, and we here place upon record that we have every confidence in the ability of Dr. Briggs to so conduct the business as to reflect credit upon the connexion.

20 Journals, I6 May I90I (see my note I9) and 9 May I9I 2. "The rumour that the Book-room had been circulating objectionable literature was introduced and a statement in rebuttal of the same was made by the Book Steward that was satisfactory to the Committee.'

21 See Board of Publication, Agreement no. 43 dated 2 March I 900 between Copp, Clark, W.J. Gage and William Briggs:

In order ... to secure a uniformity in the discounts allowed upon School Books, we hereby agree that from this date forward we will sell School Text Books in Ontario at not large discounts or better terms than arranged for in the following paragraphs....

22 RG2, Archives of Ontario.

2323 April I 896 and 9 December 1904. Box 17, RG2 D-7, Archives of Ontario. See William Briggs to George W. Ross, 23 April I896:

If you have time to take a glance through these lists, and note the character of the publications, you will find out of over 200 books not more than 20 or 25 of them could be called distinctively religious books. There are, of course, a number of moral tales, but the number of works of History, travels, science, etc. entitles us to some standing as a Publishing House, and effectually refutes the allegations made by those who are not disposed to give us more credit than we deserve.

It is not in any intention of boasting that I claim that in the way of bringing out distinctively Canadian literature the Book Room has done more than all the other publishing houses in Canada combined. You will notice, too, the number of works of Canadian History that have issued from our presses.

24 See Alison Prentice, The School Promoters: Education and Social Class in Mid-Nineteenth Century Upper Canada (Toronto: McClelland and Stewart, I977), passim; and Susan E. Houston, 'Politics, Schools, and Social Change in Upper Canada,' Canadian Historical Review 53, no. 3 (September 1972): 249-7I. 
25 See George H. Cornish, Hand-Book of Canadian Methodism, Being an Alphabetical Arrangement of All the Ministers and Preachers Whose Names Have Appeared in Connection with Canadian Methodism; Also, of All the Circuits and Missions under the Care of the Wesleyan Conference in Canada. Together with a Large Amount of Other Useful and Statistical Information (Toronto: Wesleyan Book and Job Printing Establishment, I867); and Cyclopaedia of Methodism in Canada, Containing Historical, Educational, and Statistical Information, Dating from the Beginning of the Work in the Several Provinces of the Dominion of Canada, and Extending to the Annual Conference of I880 (Toronto: Methodist Book and Publishing House, I $88 \mathrm{I}$ ). A second volume of the latter was published in 1903 covering the period from $188 \mathrm{I}$ to 1903 .

26 The Doctrines and Discipline of the Methodist Episcopal Church in Canada (York: Published by E. Ryerson and F. Metcalfe, for the Methodist Episcopal Church in Canada, 1829|. Editions of the Doctrines and Discipline for the years I 829, I 834, I836, I850, I859, I864, and I 870 are available in the Baldwin Room, Metropolitan Toronto Reference Library.

27 See no. I I97a in Fleming, Upper Canadian Imprints, 3 I 5-I 6.

28 Agreement no. 46. See also note 25.

29 I have a database of 308 titles not listed in W. Stewart Wallace's checklist, The Ryerson Imprint (Toronto: Ryerson Press, 1954), and many more titles in my research notes which I have not yet had time to add to this database.

30 Boxes 6-10, Board of Publication Collection.

3 I Henry Morgan, ed., The Canadian Men and Women of the Time: $A$ Handbook of Canadian Biography (Toronto: William Briggs, I898). 2nd ed., I9I 2. See files 2 I-23, box 10.

32 Agreements nos. 4I-43. See also Parker, Beginnings of the Book Trade in Canada, 246-47. Agreement no. 42, 27 March 1899, states:

$\ldots$ in any case where either Party to this agreement notifies the other that they have secured the Canadian market for a book, and are going to print the same in Canada, then the Party so notified shall refrain from importing any British or foreign edition of such book. Such communication to be considered confidential.

33 See I I March 1882 and following 'Miss Stafford.'

34 File 3, box 14.

35 Michael Gauvreau, The Evangelical Century: College and Creed in English Canada from the Great Revival to the Great Depression (Montreal and Kingston: McGill-Queen's University Press, I99I), 6, 45-75:

... between 1850 and 1900 the theology of the Methodist and Presbyterian churches survived the encounter with various currents of secular thought through a flexibility forged in the ambiguous evangelical encounter with the eighteenth century that permitted a constructive dialogue with certain modern thought. [John Locke and David Hume who distrusted speculative reason and exalted experience] This enabled clergymen to preserve much of their status and intellectual leadership in the wider culture until the early twentieth century. 
For these clergymen, scientific evolutionary thought was not the major intellectual challenge. Their anxieties centred on the implications of higher criticism, historical scholarship, and the insights of the social sciences for their religious outlook. For them Darwinism was merely an undercurrent. When faced with these perplexing problems, clergymen found in their theology the resources to shape and direct these newer scientific, historical, and philosophical currents.

36 Agreement no. 5. See William Briggs's agreement to publish Burwash's Wesley's Sermons, ro February I 880 : 'We will publish the book on shares, that is, if it proves a loss, you will bear half of said loss or if it proves a gain to share half the profit.' 